\title{
A new species of Microlepidogaster (Siluriformes: Loricariidae: Hypoptopomatinae) from the upper rio Paraná basin, Brazil
}

\author{
Bárbara B. Calegari and Roberto E. Reis
}

Microlepidogaster longicolla, new species, is described from the rio São João of the upper rio Paraná basin near Brasília, in central Brazil. The new species differs from M. perforatus, the only other species in this genus, by having a continuous lateral line, median lateral plate series reaching, rather than falling short of, the end of the caudal peduncle, a shorter pectoral-fin spine (13.4-16.2 vs. 18.2-21.0\% standard length), a smaller interorbital distance (38.9-43.1 vs. 47.7-53.3\% head length), and more numerous dentary teeth (16-29 vs. 12-15), in addition to several osteological features. Microlepidogaster longicolla shows a remarkable suite of secondary sexually dimorphic characters, involving the presence of a conical urogenital papilla in males, the presence of a fleshy flap along the dorsal margin of first thickened pelvic-fin ray of males, longer pelvic fin in males, and a more strongly arched first pelvic-fin ray in females.

Microlepidogaster longicolla, espécie nova, é descrita do rio São João da bacia superior do rio Paraná próximo a Brasília, no Brasil central. A espécie nova difere de $M$. perforatus, a única outra espécie do gênero, por ter linha lateral contínua, série média de placas laterais chegando até o final do pedúnculo caudal, menor espinho da nadadeira peitoral (13,4-16,2 vs. 18,2-21,0\% do comprimento padrão), menor distância interorbital (38,9-43,1 vs. 47,7-53,3\% do comprimento da cabeça), e mais dentes no dentário (16-29 vs. 12-15), além de várias características osteológicas. Microlepidogaster longicolla possui um marcado dimorfismo sexual secundário, envolvendo a presença de papila urogenital cônica em machos, a presença de uma aba carnosa ao longo da margem dorsal do primeiro raio engrossado da nadadeira pélvica em machos, a nadadeira pélvica mais longa dos machos e o primeiro raio da nadadeira pélvica mais fortemente curvado nas fêmeas.

Key words: Teleostei, Neotropical, Taxonomy, Catfish, Cascudinhos.

\section{Introduction}

Hypoptopomatinae is a subfamily of the Loricariidae including 18 genera and 110 species (Eschmeyer \& Fong, 2010), which is widely distributed throughout cis-Andean South America from Venezuela to northern Argentina (Schaefer, 2003). Microlepidogaster was described by Eigenmann \& Eigenmann (1889) to include only the typespecies $M$. perforatus, based on the following distinguishing characters: ventral surface covered with minute granular plates; dorsal fin inserted far posterior to the pelvic fins; and temporal plate perforate. Except for the dorsal-fin position, these traits are uninformative and do not distinguish Microlepidogaster from the remaining members of the Hypoptopomatinae. More recently, Schaefer (1991, 1998) conducted phylogenetic analyses of the genera of the Hypoptopomatinae and discovered several characters which are diagnostic for Microlepidogaster. These include the presence of a median rostral plate, the median series of lateral plates which terminate before the base of the caudal fin, the supraneural with a paired anterior process, the dorsal fin shifted posteriorly relative to the supraoccipital (first dorsalfin proximal radial supported by the ninth, rather than seventh vertebral centrum), and the absence of a levator crest on the hyomandibula.

The taxonomic limits between Microlepidogaster and other hypoptopomatines were uncertain prior to these phylogenetic assessments, and both Regan (1904) and Isbrücker (1980), but not Gosline (1945), considered Microlepidogaster as a junior synonym of Otocinclus Cope 1871. Nijssen \& Isbrücker (1987), however, resurrected Microlepidogaster without much explanation. This lack of clear definition has resulted in the eventual shift of several hypoptopomatine species originally described in Microlepidogaster to other genera. That was the case with species now classified as Pseudotocinclus tietensis (von Ihering, 1907), Parotocinclus doceanus (Miranda Ribeiro, 1918), Parotocinclus

Laboratório de Sistemática de Vertebrados, Pontifícia Universidade Católica do Rio Grande do Sul. Av. Ipiranga, 6681, Caixa Postal 1429, 90619-900 Porto Alegre, RS, Brazil. reis@pucrs.br 
bahiensis (Miranda Ribeiro, 1918), Hisonotus depressinotus (Miranda Ribeiro, 1918), Schizolecis guntheri (Miranda Ribeiro, 1918), and Hisonotus taimensis (Buckup, 1981).

In this paper we describe a new species of Microlepidogaster collected in a small tributary to the rio São João of the upper rio Paraná drainage near Brasília, Brazil. As we show in Discussion below, the new species is attributed to Microlepidogaster based on the possession of some of, but not all, the derived features uncovered by Schaefer (1998).

\section{Material and Methods}

Morphological measurements were made point-to-point to the nearest $0.1 \mathrm{~mm}$ with digital calipers. Methodology and terminology for counts and measurements follow Pereira et al. (2007). Four additional measurements were included: prepelvic length (measured from the snout tip to the pelvicfin origin), dorsal-fin base length (measured from the dorsalfin origin to the end of fin base), internareal width (measured horizontally between inner margins of posterior nares), prenasal length (measured from the snout tip to the anterior naris). Measurements of bilaterally symmetrical features were made on the left side of the body whenever possible. Morphometric data are expressed as percents of the standard length (SL), except subunits of the head which were expressed in percents of head length (HL). Vertebral counts include all vertebrae including the five centra modified into the Weberian apparatus, with the compound caudal centrum (PU1+U1) counted as one element. Osteological examination was made on specimens cleared and double-stained for bone and cartilage (c\&s) according to the procedure of Taylor \& van Dyke (1985). The following institutions provided material for this study: American Museum of Natural History, New York (AMNH); Academy of Natural Sciences of Philadelphia, Philadelphia (ANSP); Departamento de Zoologia e Botânica, Universidade Estadual Paulista, São José do Rio Preto (DZSJRP); Laboratório de Ictiologia Sistemática, Departamento de Ecologia e Biologia Evolutiva, Universidade Federal de São Carlos, São Carlos (LISDEBE); Museu de Ciências e Tecnologia, Pontifícia Universidade Católica do Rio Grande do Sul, Porto Alegre (MCP); Museu Nacional, Rio de Janeiro (MNRJ); and Museu de Zoologia da Universidade de São Paulo, São Paulo (MZUSP).

\section{Results \\ Microlepidogaster longicolla, new species Fig. 1}

Holotype. MCP 44877, female, 39.8 mm SL, Brazil, Distrito Federal, Brasília, ribeirão Santana, tributary to rio São João, on road from Cidade Ocidental to Brasília, 1600’55”S 4748’02”W, 13 Jul 1998, R. E. Reis, L. R. Malabarba, E. H. L. Pereira \& J. P. Silva.

Paratypes. All from Brazil. AMNH 251432, 5, 23.5-35.7 mm SL, DZSJRP 12453, 5, 39.7-44.5 mm SL, MCP 23323, 13, 18.5-42.2 mm SL, 5 c\&s, 37.7-42.5 mm SL, same locality as holotype. LISDEBE 2662, 3, 33.3-36.8 mm SL, Distrito Federal, Brasília, córrego Taquara at mouth of córrego Onça, Ecological Reserve of the Instituto Brasileiro de Geografia e Estatística - IBGE, 1556’22”S 4753’53”W, 31 Jan 1985, M. Ribeiro, E. C. Lopes \& F. Paixão. MCP 23322, 10, 18.1-36.5 mm SL, Goiás, Cidade Occidental, creek near Mesquita, on road from Cidade Ocidental to Brasília, 1655’04”S 4751’15”W, 13 Jul 1998, R. E. Reis, L. R. Malabarba, E. H. L. Pereira \& J. P. Silva. MCP 23324, 1, 38.3 mm SL, Distrito Federal, Brasília, creek on highway BR-020 between road BR-251 and Planaltina, 1544’29”S 47³9’48”W, 13 Jul 1998, R. E. Reis, L. R. Malabarba, E. H. L. Pereira \& J. P. Silva. MCP 23325, 12, 19.3-41.2 mm SL, 3 c\&s, 27.6-41.6 mm SL, Distrito Federal, Planaltina, ribeirão Mestre D’armas in Planaltina, 15³6’25”S 4741’31”W, 13 Jul 1998, R. E. Reis, L. R. Malabarba, E. H. L. Pereira \& J. P. Silva.

Diagnosis. Microlepidogaster longicolla is readily distinguished from the only other species of Microlepidogaster, M. perforatus, by having a continuous lateral line (vs. the lateral line discontinuous, with a gap between the anterior and posterior lateral line segments; Fig. 2), the median lateral plate series reaching the end of the caudal peduncle (vs. median lateral plate series terminating two plates before the end of the caudal peduncle; Fig. 2), the shorter pectoral-fin spine (13.4-16.2 vs. 18.2-21.0\% SL), a smaller interorbital distance (38.9-43.1 vs. 47.7-53.3\% HL), more numerous dentary teeth (16-29 vs. 12-15), the anterior margin of the snout naked (vs. the snout completely covered by plates), the preopercle not contacting the fourth postrostral plate (vs. the preopercle contacting and extending to midlength of that plate), the absence of the anterior processes of the supraneural ( $v s$. supraneural bearing a bilateral pair of processes along its anterior margin), and the dorsal fin located more posteriorly relative to the parietosupraoccipital, where the neural spine of the tenth or eleventh vertebral centrum supports the compound supraneural plus first pterygiophore of the dorsal fin (vs. compound supraneural plus first pterygiophore supported by the neural spine of the eighth or ninth vertebra; Fig. 3).

Description. Proportional measurements and counts given in Tables 1 and 2, respectively. Dorsal body profile slightly arched from snout tip to posterior margin of frontal bone. Parieto-supraoccipital slightly elevated and convex. Profile of the posterior region of parieto-supraoccipital and first predorsal plates slightly concave. Almost straight and slightly ascending from that point to dorsal-fin origin. Slightly concave and postero-ventrally oriented along dorsal-fin base, straight from terminus of dorsal-fin base to end of caudal peduncle and angling upward slightly immediately before caudal-fin origin. Greatest body depth located at dorsal-fin origin. Least body depth situated at posterior portion of caudal peduncle. Greatest body width along opercular and cleithral regions. Body progressively narrowing caudally from cleithrum. Ventral and especially dorsal surface of caudal peduncle transversely flattened, with caudal peduncle somewhat square in cross section. 


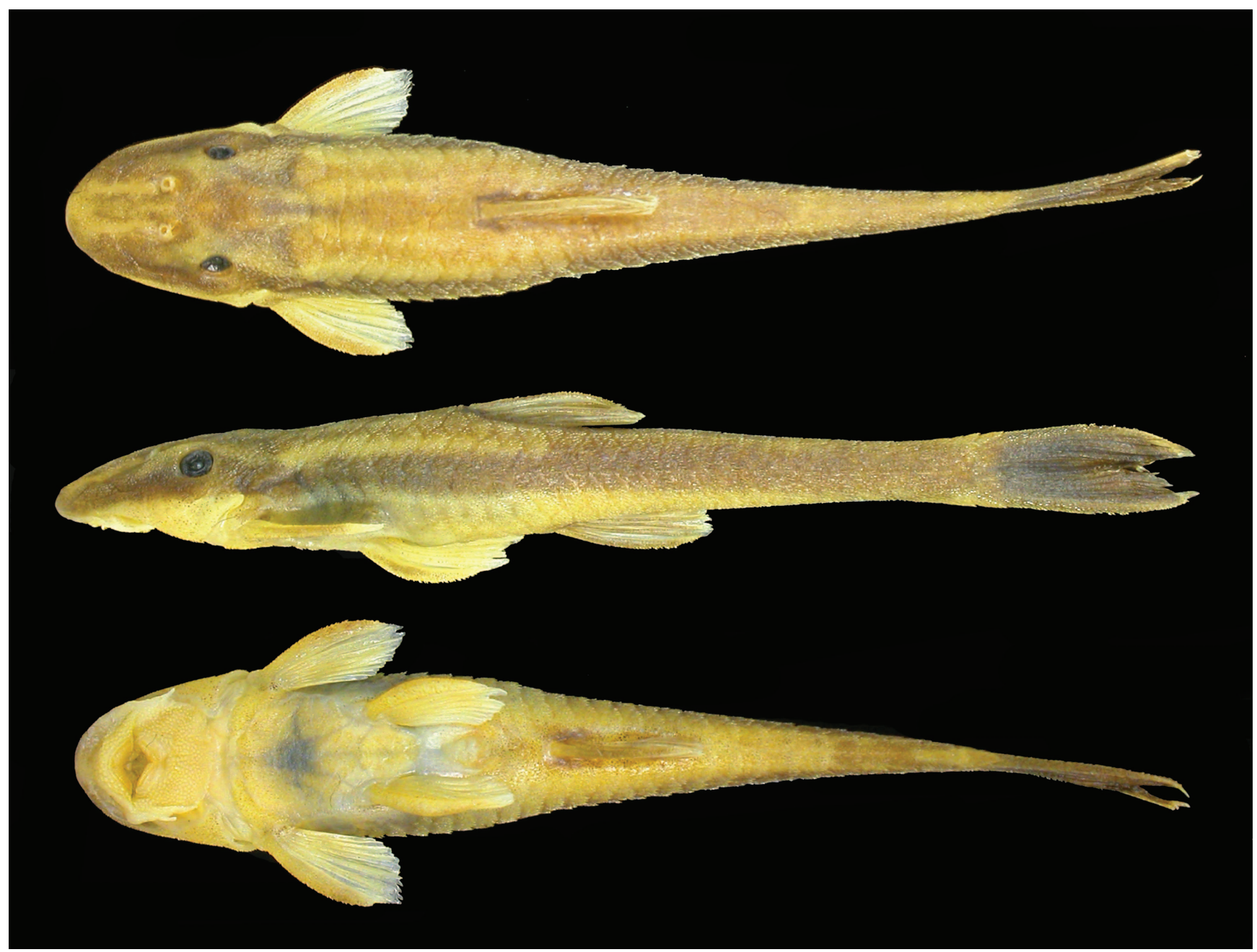

Fig. 1. Microlepidogaster longicolla, holotype, MCP 44877, female, 39.8 mm SL. Brazil, Distrito Federal, Brasília, ribeirão Santana, tributary to rio São João, on road from Cidade Ocidental to Brasília.

Head and snout broad, snout rounded in dorsal view. Region of prenasal plates between nostrils protuberant, bordered by elongate and shallow depressions extending from each nostril to near snout tip. Dorsal margin of orbit slightly elevated, interorbital region almost flat. Eye small, dorsolaterally positioned. Compound pterotic completely perforate with middle to large size fenestrae; larger fenestrae anteroventral margin.

Body surface without well-developed keels. Five or six (often six) transverse rows of predorsal plates, including nuchal plate. Lateral line continuous, with median lateral plate series formed by 27-30 plates. Odontodes on head and trunk pointed, uniform in size and distribution. Body entirely covered by plates, except region around anus, region overlying lateral opening of swimbladder capsule, depression from nostril to rostral plates, area between pectoral girdle and lower lip, and area around bases of paired fins. Abdominal region entirely covered with small platelets. Lateral abdominal plates absent. Ventral portions of cleithrum and coracoid exposed and supporting odontodes laterally, covered with skin and median abdominal plates medially. Lips rounded and papillose. Lower lip falling short of line between ventral tips of contralateral canal-bearing lateral cheek plates. Teeth slender, bifid, with blade-like larger medial cusp and smaller lateral cusp.

Dorsal-fin II,7, its origin located at vertical running close to posterior rim of anus. Dorsal fin located distinctly posterior of parieto-supraoccipital. Neural spine of tenth (3 c\&s specimens) or eleventh (2 c\&s specimens) vertebra (Fig. 3) supporting compound supraneural plus first dorsal-fin

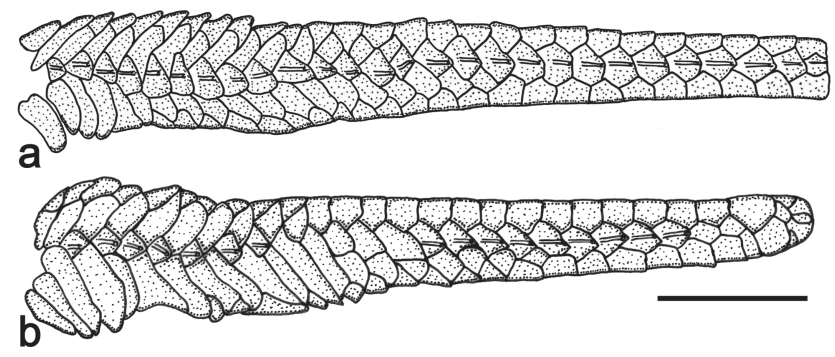

Fig. 2. Lateral plates of species of Microlepidogaster. a) Microlepidogaster longicolla, MCP 23323; b) M. perforatus, MCP 17717. Scale bar $=5 \mathrm{~mm}$. 
Table 1. Morphometrics of species of Microlepidogaster. Values are given for holotype and nine paratypes of M. longicolla. $\mathrm{SD}=$ Standard deviation .

\begin{tabular}{|c|c|c|c|c|c|c|c|c|c|}
\hline & \multicolumn{5}{|c|}{$\begin{array}{l}\text { Microlepidogaster longicolla } \\
\mathrm{n}=10\end{array}$} & \multicolumn{4}{|c|}{$\begin{array}{c}\text { Microlepidogaster perforatus } \\
\mathrm{n}=9\end{array}$} \\
\hline & Holotype & Low & High & Mean & SD & Low & High & Mean & $\mathrm{SD}$ \\
\hline Standard length (mm) & 39.8 & 33.6 & 42.2 & 37.5 & - & 27.6 & 33.7 & 30.8 & - \\
\hline \multicolumn{10}{|c|}{ Percents of standard length } \\
\hline Head length & 24.0 & 22.6 & 27.7 & 24.9 & 1.81 & 25.5 & 28.2 & 26.8 & 0.93 \\
\hline Predorsal length & 45.6 & 44.9 & 49.8 & 46.6 & 1.69 & 44.9 & 48.5 & 46.8 & 1.12 \\
\hline Postdorsal length & 44.1 & 39.4 & 46.2 & 44.0 & 2.29 & 42.4 & 44.9 & 43.7 & 0.88 \\
\hline Preanal length & 54.3 & 53.6 & 58.4 & 55.3 & 1.60 & 55.7 & 60.0 & 57.9 & 1.41 \\
\hline Prepelvic length & 34.0 & 32.7 & 37.7 & 35.1 & 1.63 & 36.1 & 38.5 & 37.3 & 0.77 \\
\hline Cleithral width & 20.1 & 18.2 & 22.0 & 20.1 & 1.15 & 21.1 & 24.1 & 22.9 & 0.90 \\
\hline Thorax length & 13.6 & 13.0 & 14.9 & 13.7 & 0.67 & 13.7 & 16.5 & 14.8 & 0.97 \\
\hline Abdomen length & 20.9 & 19.5 & 22.1 & 21.0 & 0.85 & 20.6 & 22.8 & 21.7 & 0.79 \\
\hline Dorsal-fin spine length & 18.0 & 17.0 & 20.6 & 18.8 & 1.20 & 17.9 & 21.1 & 19.6 & 1.32 \\
\hline Base of dorsal-fin length & 10.5 & 9.1 & 11.5 & 10.3 & 0.78 & 10.8 & 12.3 & 11.6 & 0.62 \\
\hline Pectoral-fin spine length & 15.3 & 13.4 & 16.2 & 14.9 & 0.98 & 18.2 & 21.0 & 19.2 & 0.91 \\
\hline Pelvic-fin unbranched ray length & 13.9 & 13.4 & 18.7 & 16.0 & 1.94 & 12.5 & 17.7 & 14.9 & 1.81 \\
\hline Anal-fin unbranched ray length & 16.6 & 14.7 & 17.7 & 16.5 & 1.05 & 16.6 & 19.2 & 18.0 & 0.85 \\
\hline Caudal-peduncle length & 37.2 & 37.1 & 45.9 & 39.3 & 2.76 & 42.0 & 46.1 & 43.8 & 1.39 \\
\hline Caudal-peduncle depth & 6.6 & 5.4 & 7.3 & 6.5 & 0.63 & 6.5 & 7.5 & 7.0 & 0.30 \\
\hline Caudal-peduncle width & 3.9 & 2.9 & 4.6 & 3.7 & 0.53 & 3.7 & 4.3 & 3.9 & 0.19 \\
\hline Body depth at dorsal-fin origin & 13.9 & 10.9 & 13.9 & 12.4 & 1.01 & 12.9 & 14.6 & 13.8 & 0.69 \\
\hline Body width at dorsal-fin origin & 16.1 & 13.1 & 16.1 & 14.4 & 0.99 & 13.0 & 18.0 & 15.3 & 1.71 \\
\hline \multicolumn{10}{|c|}{ Percents of head length } \\
\hline Snout length & 68.0 & 65.7 & 70.8 & 68.4 & 1.93 & 60.8 & 68.5 & 64.7 & 2.26 \\
\hline Orbital diameter & 14.6 & 12.8 & 17.1 & 14.7 & 1.21 & 13.9 & 15.6 & 14.8 & 0.48 \\
\hline Interorbital width & 42.8 & 38.9 & 43.1 & 41.0 & 1.49 & 47.7 & 53.3 & 50.6 & 2.09 \\
\hline Internareal width & 10.9 & 10.4 & 13.5 & 11.7 & 0.96 & 13.0 & 15.8 & 14.2 & 0.97 \\
\hline Prenasal length & 48.3 & 45.1 & 48.7 & 46.6 & 1.22 & 41.6 & 49.0 & 44.7 & 2.32 \\
\hline
\end{tabular}

proximal radial. Supraneural without pair of processes along anterior margin. Spinelet reduced and plate-like, and dorsalfin locking mechanism non functional. Adipose fin absent. Pectoral fin I,6, with posterior fin margin slightly rounded. Tip of depressed pectoral fin extending one-third of pelvicfin length. Axillary slit of pectoral fin absent. Pelvic fin i,5, short, with robust thickened first ray. Tip of adpressed fin extending to point midway between anus and anal-fin origin in females. Reaching to or beyond anal-fin origin in males. Adult males with fleshy flap along posterodorsal margin of thickened first pelvic-fin ray. Anal fin i,5. Caudal fin i,14,i.

Color in alcohol. Ground color of dorsal surface of head and body light to median brown; pale yellowish, mostly unpigmented ventrally. Longitudinal dark brown stripe present on lateral surface of head and body. Stripe begins laterally on snout tip and extends to end of caudal peduncle. Four inconspicuous darker saddles on dorsal surface of body. First saddle at dorsal-fin origin, second behind dorsal-fin base, third and fourth between dorsal and caudal fins. Head with two light stripes from snout tip to nares. Dorsal margin of orbital with creamy white light stripes, extending to posterodorsal margin of compound pterotic and then along middorsal series of lateral plates to around middle of dorsalfin base. Parieto-supraoccipital with two creamy stripes, diverging and prolonged along predorsal plates to end of dorsal-fin base. Ventrolateral margin of head from upper lip to opercle and pectoral-fin insertion creamy white, and strongly contrasting with longitudinal dark brown stripe. Ventral surface from lips to anterior margin of cleithrum and abdominal region mostly unpigmented. Caudal peduncle with scattered dark chromatophores. All fins mostly hyaline with chromatophores forming scattered spots most conspicuous on unbranched rays; dorsal-fin base more densely pigmented. Caudal fin uniformly dark-brown, except for distal tips of upper rays sometimes with small hyaline area.

Table 2. Frequency of distribution of meristic data for Microlepidogaster longicolla. Holotype values are marked with an asterisk. cs $=$ Counted in c\&s specimens. $\mathrm{N}=$ number of specimens.

\begin{tabular}{lccl}
\hline \multicolumn{1}{c}{ Character } & $\mathrm{N}$ & Range & \multicolumn{1}{c}{ Frequency distribution } \\
\hline Left premaxillary teeth & 10 & $17-27$ & $17(2), 18(1), 20(1), 21(2), 23(1)^{*}, 24(1), 25(1), 27(1)$ \\
Right premaxillary teeth & 10 & $18-29$ & $18(3), 19(1), 20(1), 22(1), 24(2), 25(1)^{*}, 29(1)$ \\
Left dentary teeth & 10 & $16-28$ & $16(1), 17(2), 18(1), 20(1), 21(2)^{*}, 22(1), 26(1), 28(1)$ \\
Right dentary teeth & 10 & $16-29$ & $16(1), 17(1), 18(1), 19(2), 23(1), 24(2)^{*}, 25(1), 29(1)$ \\
Plates in median lateral series (cs) & 6 & $27-29$ & $27(3), 28(1), 29(1), 30(1)$ \\
Plates between anal and caudal fin & 10 & $11-12$ & $11(8)^{*}, 12(2)$ \\
Plates at dorsal-fin base & 10 & 5 & $5(10)^{*}$ \\
Plates at anal-fin base & 10 & $3-4$ & $3(1), 4(9)^{*}$ \\
Predorsal plates & 13 & $5-7$ & $5(2), 6(8) *, 7(3)$ \\
Vertebrae (cs) & 5 & $31-33$ & $31(3), 33(2)$ \\
\hline
\end{tabular}



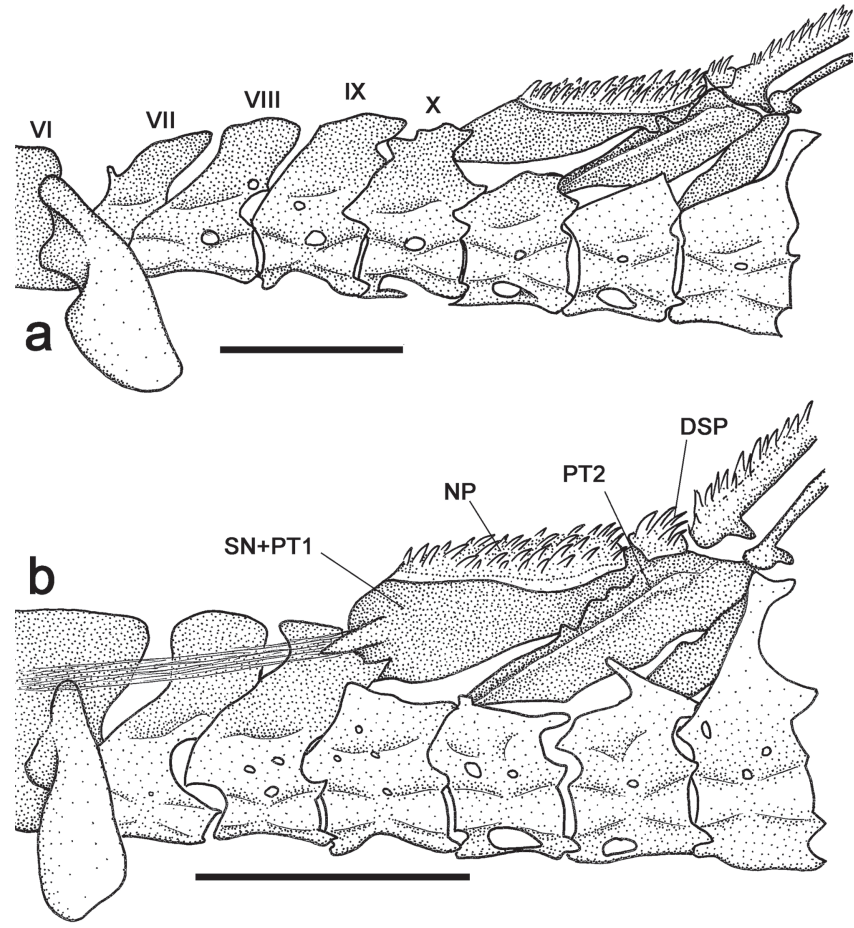

Fig. 3. Dorsal-fin skeleton of Microlepidogaster. a) Microlepidogaster longicolla, MCP 23323; b) M. perforatus, MCP 17717. DSP = dorsal-fin spinelet; $\mathrm{NP}=$ nuchal plate; $\mathrm{PT} 2$ = second dorsal-fin pterygiophore; $\mathrm{SN}+\mathrm{PT} 1$ = fused supraneural and first dorsal-fin pterygiophore; VI-X = vertebrae $\mathrm{VI}^{\text {th }}$ to $\mathrm{X}^{\text {th }}$. Scale bar $=2 \mathrm{~mm}$.

Sexual dimorphism. Secondary sexual dimorphism in Microlepidogaster longicolla is most obvious in the conical urogenital papilla, which is positioned just behind the anal opening in males; absent in females. Adult males also possess a fleshy flap along the dorsal margin of first thickened pelvicfin ray that is absent in females. Males have a longer pelvicfin extending to the anal-fin origin, whereas the pelvic fin never reaches that point in females. The first thickened pelvicfin ray is strongly arched in female; but straight in males.

Distribution. Microlepidogaster longicolla is known from five localities in the upper reaches of the rio São Bartolomeu, a tributary to the rio Corumbá, itself a tributary to the rio Paranaíba of the upper rio Paraná basin near Brasília, in central Brazil (Fig. 4).

Etymology. The species epithet, longicolla, is from the Latin longus, long and collum, neck, meaning long-necked in allusion to the long predorsal region resulting from the posterior shift of the dorsal fin. An adjective.

\section{Discussion}

Previous studies of the phylogenetic relationships of the Hypoptopomatinae by Schaefer (1998) uncovered five autapomorphies for Microlepidogaster perforatus, the only species in the genus at that time. The dorsal fin is shifted

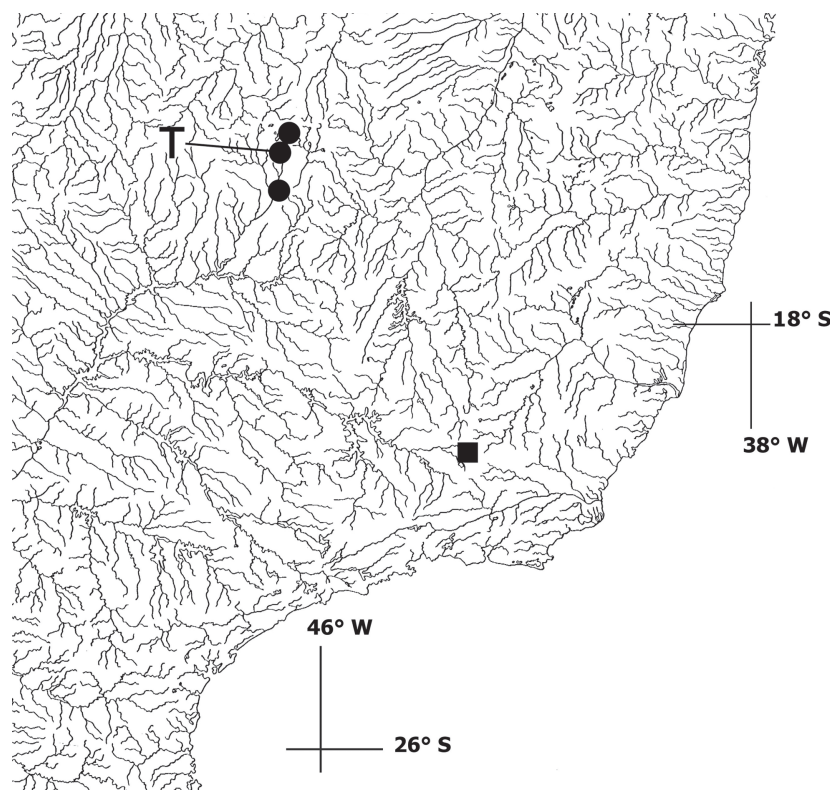

Fig. 4. Map of southeastern Brazil showing the distribution of Microlepidogaster longicolla (circles) and M. perforatus (square). $\mathrm{T}=$ type-locality. Each symbol may represent more than one locality.

posteriorly relative to the parieto-supraoccipital (character 26, state 1) in both $M$. perforatus and the species of Epactionotus, with the compound supraneural-first dorsalfin proximal radial articulating to the neural spine of the eighth or ninth centrum. In $M$. longicolla the dorsal fin is displaced further posteriorly, and the compound first pterygiophore articulates with the neural spine of the tenth or eleventh vertebral centrum. Microlepidogaster longicolla is assigned to Microlepidogaster mainly based on the possession of this synapomorphy. A second character of note is a crest on the hyomandibula for the insertion of the levator arcus palatini muscle (character 14), which Schaefer (1998) considered as absent in M. perforatus (state 1). Contrary to Schaefer's observation, however, we identified a low levator crest in that species. This condition is shared with the new species which possesses, however, a higher and more robust form of the crest. This feature is not diagnostic of Microlepidogaster as it represents the basal state for that character, which is shared by most hypoptopomatines.

Three other derived characters recovered by Schaefer (1998) as autapomorphic of M. perforatus are not shared with the new species, and remain as autapomorphies of the typespecies. Microlepidogaster perforatus bears a bilaterally paired anterior process from the anterior supraneural margin that ligamentously connects the supraneural with the parietosupraoccipital (character 28, state 1). That process is absent in M. longicolla. Microlepidogaster perforatus has a pair of median rostral plates covering the anterior tip of the rostrum (character 34, state 1). In M. longicolla the anterior margin of the snout is unplated. Finally, the truncated median plate series that terminates anterior to the caudal-fin base (character 33 , state 1) remains as an autapomorphy of $M$. perforatus. 
This truncation involves only the caudal extreme of the median series, such that only the last two plates of the dorsal and ventral series contact each other along the lateral midline. The new species retains the plesiomorphic condition in which the median plate series is complete and extends posteriorly such that the ultimate plate contacts the marginal plates overlapping the principal caudal-fin rays. The genus Microlepidogaster is thus re-diagnosed by its species sharing the possession of a dorsal fin shifted posteriorly, with the compound first pterygiophore articulating with neural spine of at least the eight vertebral centrum.

The species of Microlepidogaster have allopatric distributions, occurring in the separate headwaters of rio São João (M. longicolla) and rio Carandaí (M. perforatus), both part of the upper rio Paraná basin.

Comparative material. All specimens from Brazil. Epactionotus bilineatus: MCP 29293, 29 + 3 c\&s, Rio Grande do Sul, Itati, arroio das Bananeiras, tributary to rio Três Forquilhas, 29²5'28”S 50¹0'19”W. Hisonotus nigricauda: MCP 26865, $89+3$ c\&s, Rio Grande do Sul, Rosário do Sul, arroio do Salso at road BR-158, tributary to rio Ibicuí da Armada, 30²7'22”S 5502'07’W. Lampiella gibbosa: MCP 31588, 1 + 1 c\&s, São Paulo, Barra do Turvo, rio Bonito, tributary to rio Pardo, 2450'13”S 48²9'27”W. Microlepidogaster perforatus: MCP 17717, 4 + 1 c\&s, and ANSP 174718, 1 c\&s, Minas Gerais, Carandaí, rio Carandaí, tributary to rio Grande, above Carandaí, 2057’17’'S 4346’41’W. MNRJ 31886, 6 + 2 c\&s (of 13), Minas Gerais, Carandaí, rio Carandaí, tributary to rio Paraná upstream Carandaí at bairro Ponte Alta, 2057'12”S 4346’34”W. Otothyris travassosi: MCP 18105, $30+2$ c\&s, rio Braço Norte, tributary to rio São Mateus on road ES-130 near Boa Esperança, 18²9'46”S 40¹5'55”'W. Otothyropsis marapoama: MCP 38303, 9 + 1 c\&s, São Paulo, Catanduva, córrego Cubatão at Fazenda Cubatão, rio Tietê drainage, 21¹4'53”S 4901'18”W. MCP 42119, 1 c\&s, São Paulo, Gavião Peixoto, rio Boa Esperança, tributary to rio Jacaré-Guaçu, rio Tietê drainage, 2150’02”S 48³1’17”W. Pseudotocinclus juquiae: MZUSP 79048, 2 paratypes, and MCP 45129, 2 + 2 c\&s, São Paulo, Juquitiba, córrego na Fazenda Estio, on road from Santa Rita to Juquitiba, ca. 8 km S of Santa Rita, 2359'50”S 4656’01”W. Pseudotocinclus parahybae: MZUSP 83611, paratype, MZUSP 47581, 1 c\&s paratype, and MCP 45094, 4 + 1 c\&s, São Paulo, Pindamonhangaba, creek tributary to Ribeirão Grande at Fazenda São Sebastião do Ribeirão Grande, 2247’06”S 45²7’20’W. Pseudotocinclus tietensis: MCP 20090, 2 + 1 c\&s, São Paulo, Salesópolis, riacho Paraitinguinha on road from Salesópolis to Jacareí, 2330'45”'S 4552'15”'W. Pseudotothyris obtusa: MCP 31728, 7 + 2 c\&s, São Paulo, Itanhaém, creek tributary to rio Preto, ca. 2 km from airport, 2408'37’'S 4646'34”W. Schizolecis guntheri: MCP 31558, 100 + 3 c\&s, Rio de Janeiro, Parati, rio São Roque on highway BR-

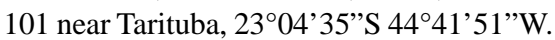

\section{Acknowledgements}

We are grateful to Edson H. L. Pereira, Fernando C. Jerep, Pablo Lehmann, Tiago P. Carvalho, and Fernanda Martins for their comments and discussions on loricariid anatomy and systematics. We thank Francisco Langeani (DZSJRP), Julio C. Garavello (LISDEBE), and Paulo A. Buckup (MNRJ) for loans of specimens and for discussions. We also express our gratitude for financial support to the Conselho Nacional de Desenvolvimento Científico e Tecnológico (processes CNPq 134901/2008-8 for BBC and 303362/2007-3 for RER).

\section{Literature Cited}

Eigenmann, C. H. \& R. S. Eigenmann. 1889. Preliminary notes on South American Nematognathi, II. Proceedings of the California Academy of Sciences, 2: 28-56.

Eschmeyer, W. N. \& J. D. Fong. 2010. Species of fishes by family/ subfamily. On-line version dated 24 March 2010. http:// research.calacademy.org/research/ichthyology/catalog/ speciesbyfamily.asp. Accessed May 25, 2010.

Gosline, W. A. 1945. Catálogo dos Nematognatos de água-doce da América do Sul e Central. Boletim do Museu Nacional, Nova Série, 33: 1-138.

Isbrücker, I. J. H. 1980. Classification and catalogue of the mailed Loricariidae (Pisces, Siluriformes). Verslagen en Technische Gegevens, Instituut voor Taxonomische Zoölogie (Zoölogisch Museu), Universiteit van Amsterdam, 22: 1-181.

Nijssen, H. \& I. J. H. Isbrücker. 1987. Spectracanthicus murinus, nouveaux genre et espèce de Poisson-Chat cuirassé du Rio Tapajós, Est. Pará, Brésil, avec des remarques sur d'autres genres de Loricariidés. Revue Française de Aquariologie et Herpetologie, 13(4): 93-98.

Pereira, E. H. L., F. Vieira \& R. E. Reis. 2007. A new species of sexually dimorphic Pareiorhaphis Miranda Ribeiro, 1918 (Siluriformes: Loricariidae) from the rio Doce basin, Brazil. Neotropical Ichthyology, 5(4): 443-448.

Regan, C. T. 1904. A monograph of the fishes of the family Loricariidae. Transactions of the Zoological Society of London, 17(1): 191-350.

Schaefer, S. A. 1991. Phylogenetic analysis of the loricariid subfamily Hypoptopomatinae (Pisces: Silurioidei), with comments on generic diagnoses and geographic distribution. Zoological Journal of the Linnean Society, 102: 1-41.

Schaefer, S. A. 1998. Conflict and resolution: impact of new taxa on phylogenetic studies of the neotropical cascudinhos (Siluroidei: Loricariidae). Pp. 375-400. In: Malabarba, L. R., R. E. Reis, R. P. Vari, Z. M. S. Lucena \& C. A. S. Lucena (Eds.). Phylogeny and Classification of Neotropical Fishes. Porto Alegre, Edipucrs, 603p.

Schaefer, S. A. 2003. Hypoptopomatinae. Pp. 321-329. In: Reis, R. E., S. O. Kullander \& C. J. Ferraris, Jr. (Eds.). Checklist of the Freshwater Fishes of South and Central America. Porto Alegre, Edipucrs, 729p.

Taylor, W. R. \& G. C. van Dyke. 1985. Revised procedures for staining and clearing small fishes and other vertebrates for bone and cartilage study. Cybium, 9(2): 107-119.

Accepted June 23, 2010 Published September 24, 2010 